\title{
Unusual Nucleophilic Addition of Grignard Reagents in the Synthesis of 4-Amino-pyrimidines
}

\author{
Ryan A. J. Tinson, David L. Hughes, Leanne Ward, and G. Richard Stephenson*(1) \\ School of Chemistry, University of East Anglia, Norwich Research Park, Norwich, Norfolk NR4 7TJ, U.K. \\ Supporting Information
}

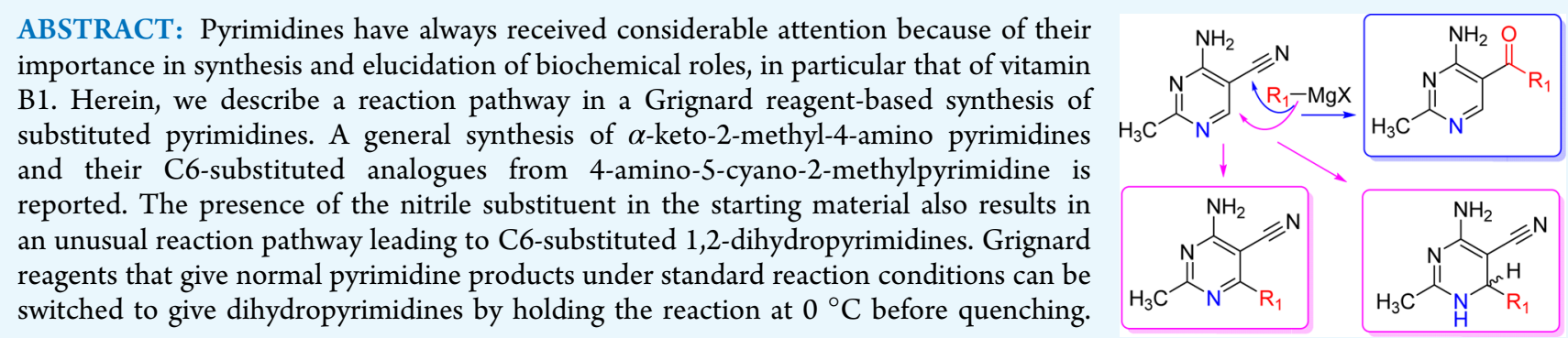

\section{INTRODUCTION}

The synthesis of pyrimidines has always been a priority topic for investigation because of their widespread use as scaffolds in medicinal, pharmaceutical, and academic chemistries. Recently, there has been a marked return to prominence of these structures, particularly in the functionalized amino pyrimidine series, ${ }^{1}$ as synthetic targets. Although a majority of these examples are 2-amino pyrimidines, examples of $4-^{2}$ and 6aminopyrimidines $^{3}$ are also notable features. These vital building blocks of life are found in many biologically significant molecules, including structures like DNA 1, drugs such as zidovudine 2, , $^{4}$ and barbiturate sodium thiopental 3 (Figure 1). Pyrimidines are also investigated for the treatment of the neurological disorders Beriberi and Korsakoff syndrome and as a recognition motif for binding in thiamine diphosphatedependent enzymes (compound 4, Figure 1). ${ }^{6,7}$

Because of their versatile hydrogen-bonding interactions, these small fragments have been intensively investigated by medicinal chemists during the past decade. Their applications

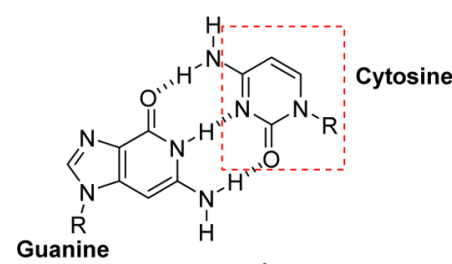

DNA 1<smiles>CCCC1(CC)C=CC=C1C(=O)NC(=S)NC</smiles>

Sodium thiopental 3

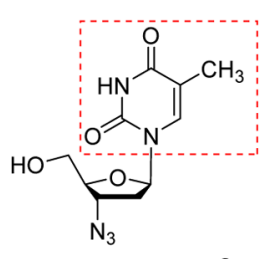

Zidovudine 2

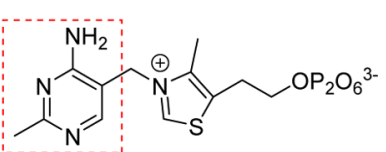

Vitamin $B_{1} 4$
Figure 1. (a) DNA fragment, HIV drug zidovudine, sodium thiopental, and vitamin $B_{1}$. in GSK's antimalaria drug trimethoprim $\mathbf{5}^{8}$ antibiotic bacimethrin $6{ }^{9}$ and in the treatments of thiamine deficiency, ${ }^{10-12}$ are well-documented (Figure 2).<smiles>COc1cc(Cc2cnc(N)nc2N)cc(OC)c1OC</smiles><smiles>COc1ncc(CO)c(N)n1</smiles>

Trimethoprim 5

Figure 2. Aminopyrimidines in GSK's trimethoprim and antibiotic bacimethrin.

Commonly, the synthesis of pyrimidine rings utilizes a sodium alkoxide-catalyzed condensation reaction between urea, an aldehyde, and a malonic ester. Most methodologies to form these rings utilize this process, now called the Biginelli reaction. ${ }^{13-15}$ Assembly of the core aromatic structure permits further functionalization with a range of reactive groups. The initial synthetic strategies to access the valuable 4-amino-2methyl pyrimidine substitution pattern were originally developed by Williams ${ }^{16}$ (Scheme 1). The reported procedure is outlined below and was subsequently modified by others for the development and production scale-up of vitamin $B_{1}$ synthesis.

Although the 4-amino-2-methyl pyrimidines have been investigated with many differing structural modifications, ${ }^{17-19}$ there are very few examples for the synthesis of $\alpha$-keto-4amino-2-methyl pyrimidines and their analogues. ${ }^{20}$ As the core pyrimidine ring is observed widely throughout nature, it was surprising to find such a lack of examples because these $\alpha$-keto

Received: May 25, 2018

Accepted: July 18, 2018

Published: August 10, 2018 
Scheme 1. Williams' Synthesis of 4-Amino-2-methyl Pyrimidine

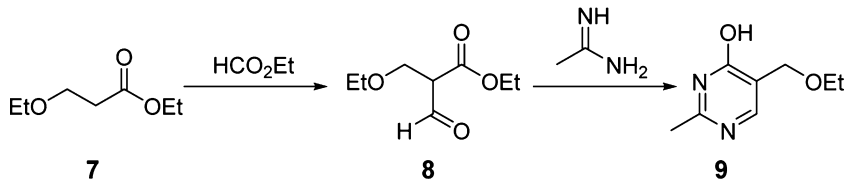<smiles>CCOCc1cnc(C)nc1NCCOc1cnc(C)nc1Cl</smiles>

structural analogues could be good candidates for inhibitor mimics and for potential structural manipulations in structureactivity relationship studies. To address this issue, we have devised a new synthetic route, which uses cheap and readily available starting materials, to construct $\alpha$-keto-4-amino-2methyl pyrimidines.

\section{RESULTS AND DISCUSSION}

Our approach to $\alpha$-keto-4-amino-2-methyl pyrimidines is based on the inclusion of a nitrile substituent at the 5-position to enable the introduction of a wide variety of $\mathrm{R}$ groups. This allows us to exploit the easy availability of 2-methyl-4-amino-5cyano-pyrimidines (Scheme 2 ). ${ }^{17}$

Scheme 2. Synthetic Approach to Access $\alpha$-Keto-4-amino-2methyl Pyrimidines with a Wide Variety of $R$ Groups

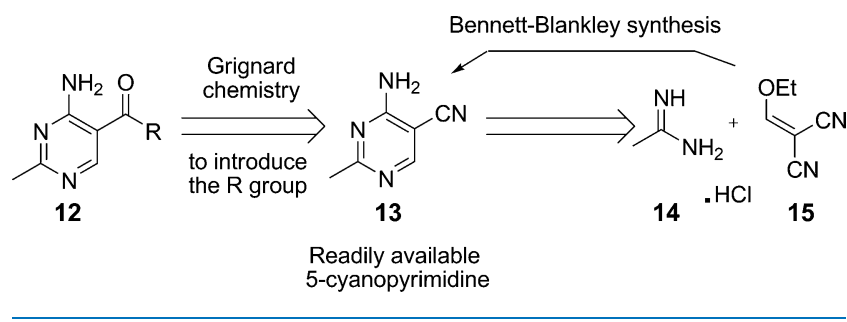

Thus, our synthesis of a range of differently substituted $\alpha$ keto-2-methyl-4-amino pyrimidines began by employing the established condensation reaction of cheap and accessible reagents, acetamidine hydrochloride 14 and ethoxymethylenemalonitrile 15, which after recrystallization of the crude product from ethanol gave the required nitrile 13 in a $78 \%$ yield (Scheme 3, step 1). ${ }^{17}$

Scheme 3. New Synthesis of the Pyrimidyl Ketones

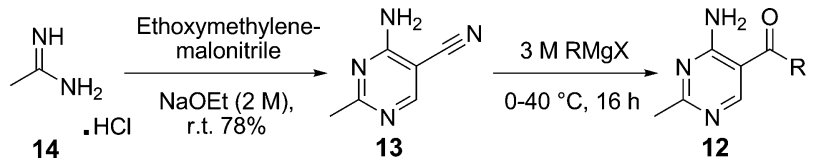

We now turned to a series of preliminary experiments to assess the optimum temperature for addition of the Grignard reagent to the nitrile. Addition of the Grignard reagent at $0{ }^{\circ} \mathrm{C}$ and warming to $40{ }^{\circ} \mathrm{C}$ gave total consumption of the starting material after $16 \mathrm{~h}$. Lower temperatures resulted in incomplete consumption and required longer reaction times. Addition of the appropriate Grignard reagent produced the desired keto products 12 with various $\mathrm{R}$ groups after simple column chromatography in yields of $16-68 \%$ (see Scheme 4 and Table
Scheme 4. Surprising Range of Products Isolated from the Addition of Grignard Reagents to the Nitrile-Substituted Aminopyrimidine

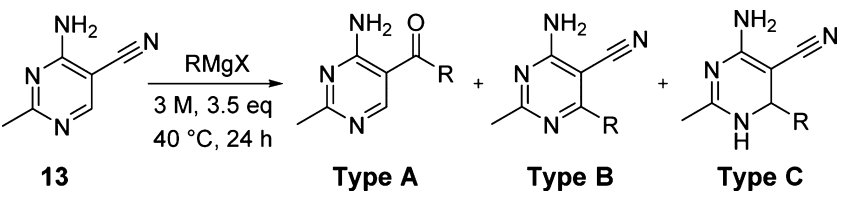

1, product type A). The infrared spectra of the products showed an unusually low position for the $\mathrm{C}=\mathrm{O}$ stretching

Table 1. Product Structures and Yields of Grignard Addition Products A, B, or C

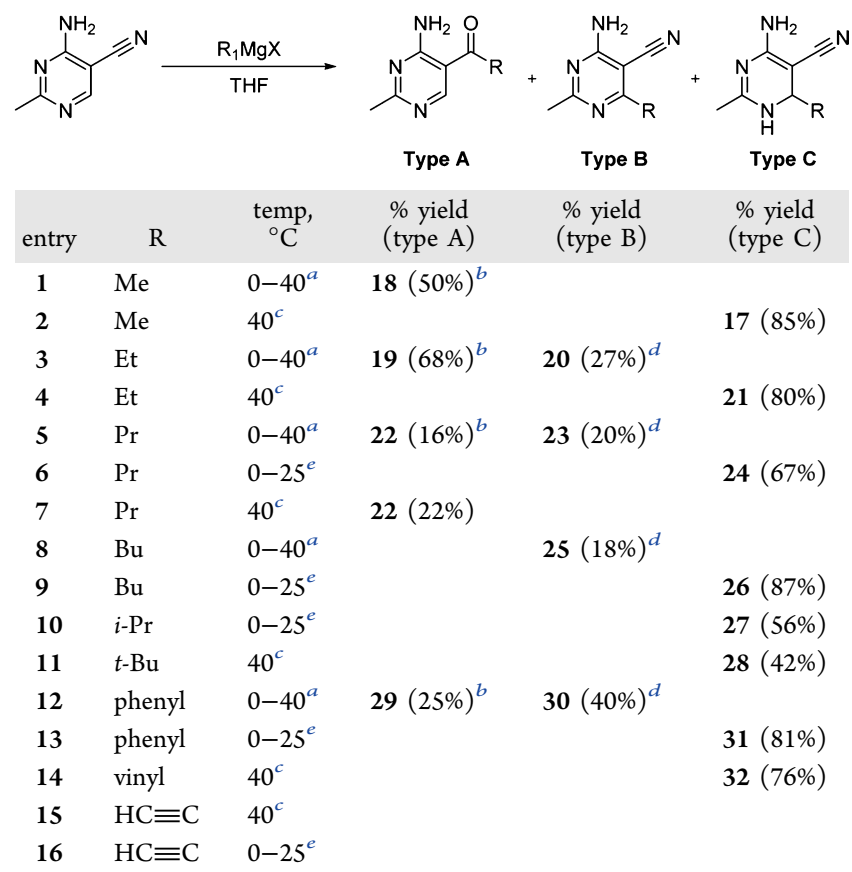

${ }^{a}$ Grignard reagent was added at $0{ }^{\circ} \mathrm{C}$, and the reaction mixture was then warmed to $40^{\circ} \mathrm{C}$ and then left to cool and stirred at rt overnight. ${ }^{b}$ By procedure I. ${ }^{c}$ By procedure III (Grignard reagent was added at 40 $\left.{ }^{\circ} \mathrm{C}\right) .{ }^{d}$ By procedure II (like procedure I but neutralized with aqueous $\mathrm{NaHCO}_{3}$, before extraction). ${ }^{e}$ By procedure IV in which the reaction temperature was maintained at $0{ }^{\circ} \mathrm{C}$ for $3 \mathrm{~h}$ before being allowed to warm to rt overnight.

vibration of the ketones at about $1650 \mathrm{~cm}^{-1}$. In the ${ }^{1} \mathrm{H}$ nuclear magnetic resonance (NMR) spectra, the signals for the $\mathrm{NH}_{2}$ protons came at two separate chemical shifts, presumably because of $\mathrm{H}$-bonding to the adjacent carbonyl oxygen by one of the protons of the amino substituent. This strong intramolecular hydrogen bonding also accounts for the unusual position of the $\mathrm{C}=\mathrm{O}$ stretching vibration for these compounds and is consistent with the data reported for 1(2-aminophenyl)ethanone. ${ }^{21}$ During the purification of our ketone products, it became apparent that other byproducts had been formed during the Grignard reaction. Characterization of these byproducts allowed us to identify some unexpected structures, which reveal an unusual alternative pathway for the addition of the Grignard reagent at the C-6 position of the pyrimidine ring (Scheme 4, product types B and C).

The formation of these unexpected substitution patterns (see Scheme 4) was apparent from the lack of the C6 aromatic proton at $\sim 8.0 \mathrm{ppm}$ in the ${ }^{1} \mathrm{H}$ NMR spectrum and the retained 


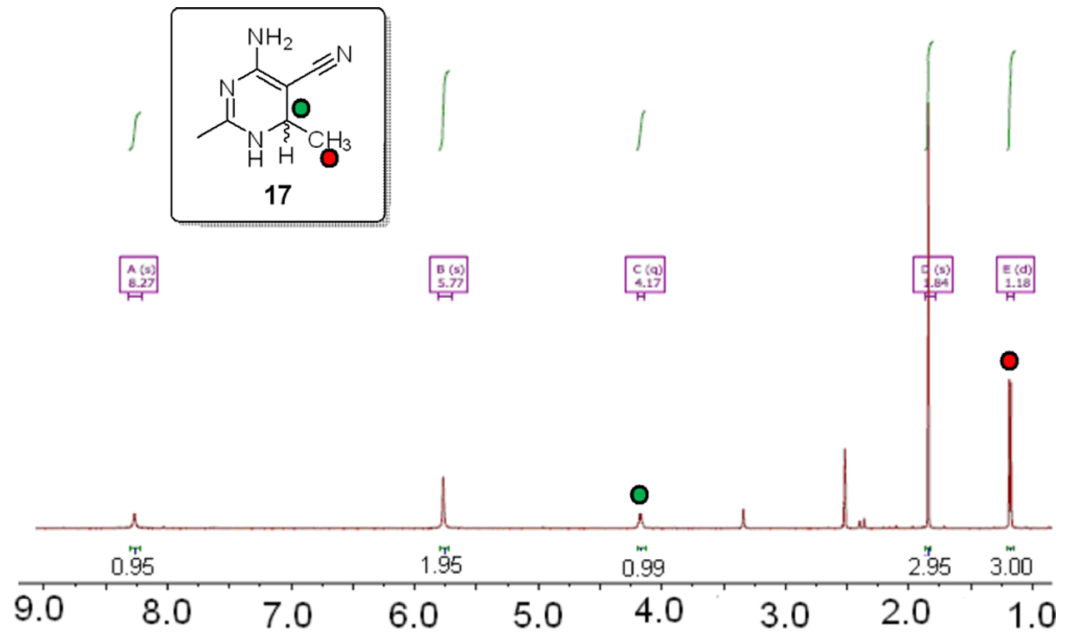

Figure 3. Structure of racemic 17 with the CHMe feature that gives a characteristic C6 quartet and C7 doublet in the ${ }^{1} \mathrm{H}$ NMR spectrum.

strong $\mathrm{C} \equiv \mathrm{N}$ stretching vibration at $2100 \mathrm{~cm}^{-1}$ in the infrared spectrum. After adjusting the reaction conditions, addition of the methyl and ethyl Grignard reagents at $40{ }^{\circ} \mathrm{C}$ instead of 0 ${ }^{\circ} \mathrm{C}$ gave the $[1,2]$-dihydropyrimidine analogues of type $\mathrm{C}$ in good yields $(80-85 \%)$. These structures were identified by the presence of the methyl signal as a doublet with ${ }^{3} \mathrm{~J}$ coupling $(6.0$ $\mathrm{Hz})$ to the $\mathrm{CH}$ proton $\left(\mathrm{q},{ }^{3} \mathrm{~J}=6.0 \mathrm{~Hz}\right)$ located at $4.1 \mathrm{ppm}$ (e.g., see Figure 3). The assignment of these spectral features was confirmed by the analysis of ${ }^{1} \mathrm{H}$ correlation spectroscopy data. The $[1,2]$-dihydro products also retained the distinctive nitrile stretch at $2100 \mathrm{~cm}^{-1}$ in their infrared spectra. The key features discussed above allow the characterization data for the products of type $\mathbf{B} / \mathbf{C}$ and the anticipated product of type $\mathbf{A}$ to be easily distinguished. Remarkably, these [1,2]-dihydro compounds remained stable at room temperature over a period of weeks, despite the loss of aromaticity following the addition of the Grignard reagent. Some aryl- ${ }^{22}$ and ferrocenylsubstituted $^{23}$ examples appear to share the same stability shown by our nitrile-substituted structures, whereas Lyle ${ }^{24}$ has reported instability in the cyano-substituted dihydropyridine analogues.

A plausible mechanism for the synthesis of side products of types B/C could arise as a consequence of the Schlenk equilibrium ${ }^{25}$ between the Grignard reagent $\mathrm{RMgX}, \mathrm{R}_{2} \mathrm{Mg}$, and $\mathrm{MgX}_{2}$. Coordination of the Lewis acidic $\mathrm{MgX}_{2}$ to the $\mathrm{N} 1$ nitrogen of the pyrimidine to form 16 would make the C6 position more electrophilic and hence promote attack by the Grignard reagent (Scheme 5). Moreover, an electron-withdrawing group adjacent to this position would further increase the electrophilicity of the C6 position providing an explanation for why, in the 5-cyano series, this side-reaction is far more favored. An alternative possibility, however, would be a radical mechanism for the transfer of the $\mathrm{R}$ group, followed by loss of $\mathrm{H}^{\bullet}$ by an oxidative step to form 17 .

Examples of reactions that are capable of forming stereogenic centers from an aromatic system using Grignard reagents are rare, but a notable precedent for this type of transformation has been described in the synthesis of antifungal agent Voriconazole by Pfizer. ${ }^{26}$ The methyl and ethyl C6-substituted analogues have been reported previously in the synthesis of vitamin $B_{1}$ analogues, but were acquired by condensation chemistry as described by Todd et al. ${ }^{27,28}$ This condensation approach has not been applied to the synthesis of other analogues containing modifications at this position, so the new
Scheme 5. Proposed Mechanism of the formation of $[1,2]$ Dihydropyrimidine 17
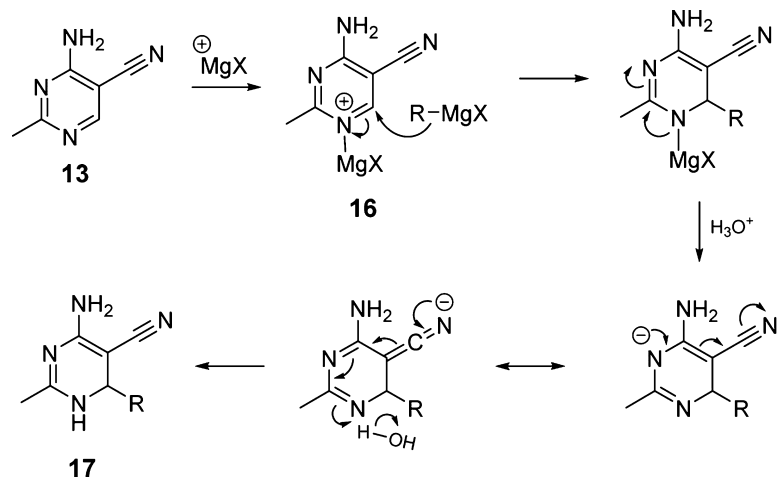

examples described here, which are obtained by the Grignard approach, will open up a general access to this class of structures.

Interestingly, the Schlenk equilibrium is often controlled by changes to the Grignard reagent, solvent, or temperature. To assess the optimum conditions, a range of temperatures from $\left(-78\right.$ to $\left.40^{\circ} \mathrm{C}\right)$ were tested, but this served only to increase the consumption of the starting nitrile $\mathbf{1 3}$ and did not affect the product outcome. It was noticeable that addition of the Grignard at $0{ }^{\circ} \mathrm{C}$ followed by warming to $40{ }^{\circ} \mathrm{C}$ gave a mixture of products, so some Grignard additions at $40{ }^{\circ} \mathrm{C}$ were attempted. As the Schlenk equilibrium should favor formation of the $\mathrm{R}_{1} \mathrm{MgX}$ species at higher temperatures and in a polar aprotic solvent, the involvement of Lewis acidic $\mathrm{MgX}_{2}$ could be reduced, and therefore C- 6 addition should be decreased. This, however, with our initial choice of methyl and ethyl Grignard reagents, gave $\mathbf{1 7}$ and $\mathbf{2 1}$ as the sole products (Table 1, entries 2 and 4).

A range of solvents were then examined to assess their affect upon product distribution. As tetrahydrofuran (THF) had already been used for the preliminary experiments, we sought to decrease the solvent polarity. Diethyl ether was tested under the same conditions, and from the analysis of the ${ }^{1} \mathrm{H}$ NMR spectra, it was obvious that only methyl ketone and the unreacted starting material were present. Attempts using 1,4dioxane resulted in the precipitation of the $\mathrm{MgX}_{2}$ salts. Removal of these $\mathrm{MgX}_{2}$ salts by filtration was expected to improve the selectivity for the formation of the ketone 
compound; however, this proved not to be the case, and the under these conditions, the attempted reaction gave only the recovered unreacted starting material.

On the basis of the mechanism proposed in Scheme 5, it seemed probable that the products that retained the nitrile group originated by initial addition of the nucleophile to the heteroaromatic ring (producing the [1,2]-dihydro product of type $\mathbf{C}$ ) and that oxidation under the reaction conditions later resulted in rearomatization to give 5-cyano-6-alkyl-2-methylpyrimidine products of type $\mathbf{B}$. This hypothesis was tested for Grignard reagents $\left(\mathrm{R}^{1}=\mathrm{Et}, \mathrm{Pr}, \mathrm{Bu}\right.$, and $\mathrm{Ph}$; Table 1 entries 3, 5,8 , and 12 ) that tended to give low yields and only products of types A and B. By avoiding the high temperature of $40{ }^{\circ} \mathrm{C}$ and keeping the reaction mixture at $0{ }^{\circ} \mathrm{C}$ for $3 \mathrm{~h}$, more time was allowed for the addition at $\mathrm{C} 6$ to go to completion before the reaction was quenched.

Under these conditions (Table 1, entries 6, 9, 10, and 13), the $[1,2]$-dihydro products of type $\mathbf{C}$ were isolated at moderate to good yields. Bulky Grignard reagents (branched $\mathrm{R}^{1}$ groups such as $i$-Pr and $t$-Bu) give poorer results (56 and $42 \%$, respectively). In the other cases, $\left(\mathrm{R}^{1}=\mathrm{Me}, \mathrm{Et}, \mathrm{Pr}\right.$, and $\left.\mathrm{Bu}\right)$, the yields of the $[1,2]$-dihydro products ranged from 67 to $87 \%$. Extending the study to phenyl- and vinylmagnesium bromide, we were able to show that the low temperature conditions worked well to improve the yields with phenylmagnesium bromide, giving [1,2]-dihydro product 31 in an $81 \%$ yield (compare entries 12 and 13), and our original $40{ }^{\circ} \mathrm{C}$ reaction conditions were suitable with vinylmagnesium bromide, giving 32 in a $76 \%$ yield.

On the basis of these trends, it appears that the unexpected formation of $[1,2]$-dihydropyrimidine is in fact the preferred addition pathway and proceeds efficiently, albeit slowly, at 0 ${ }^{\circ} \mathrm{C}$. At higher temperatures, the addition at the nitrile begins to become significant, so that reactions that are allowed to warm up before all of the Grignard reagent has been consumed can produce substantial amounts of the ketones (type A products). Type $\mathbf{B}$ products in many cases arise by rearomatization of $[1,2]$-dihydropyrimidines, accounting for the failure to isolate type $\mathbf{C}$ products in these cases. In other cases, however, the addition of the Grignard reagent can be performed at $40{ }^{\circ} \mathrm{C}$ to give methyl- and ethyl-substituted [1,2]-dihydropyrimidines in a high yield. We proposed that this difference arises from the differences in stability of type $\mathbf{C}$ products under strong acid $(\mathrm{HCl}$; entries $1,3,5,8$, and 12$)$ conditions used in the quench, compared to the weak acid (ammonium chloride) used for entries $2,4,6,7,9,10,11,13$, and 14. Steric bulk in the nucleophile (e.g., entry 8) seems to block addition at the nitrile, and type $\mathbf{A}$ products were not formed with butylmagnesium bromide. Alkynyl Grignard reagents are less reactive and $\mathrm{HC} \equiv \mathrm{CMgBr}$ failed to add to 13 , even at $40{ }^{\circ} \mathrm{C}$.

Crystallization and X-ray analysis of the simple methyl substituted example 17 confirmed the [1,2]-dihydro structure and the presence of the stereogenic center at C6 (Figure 4). C6 is displaced 0.078(2) $\AA$ from the good mean plane of the rest of the heterocyclic ring, which supports the presence of extended $\pi$-overlap into the nitrile substituent. The shorter bond length of $\mathrm{C} 1-\mathrm{C} 2[1.379(2) \AA]$ when compared to the $\mathrm{C} 1-\mathrm{C} 6$ bond of the C-CHMe $[1.510(2) \AA]$ suggests the presence of the alkene $\pi$ bond in conjugation with the nitrile substituent within the aromatic $\pi$-system.

Measurement of the CN bond length C11-N12 [1.158(2) $\AA]$ indicates a typical length for this group, although the $\mathrm{C} 1-$ $\mathrm{C} 11 \mathrm{C}-\mathrm{CN}[1.402(2) \AA]$ bond length lies between a normal

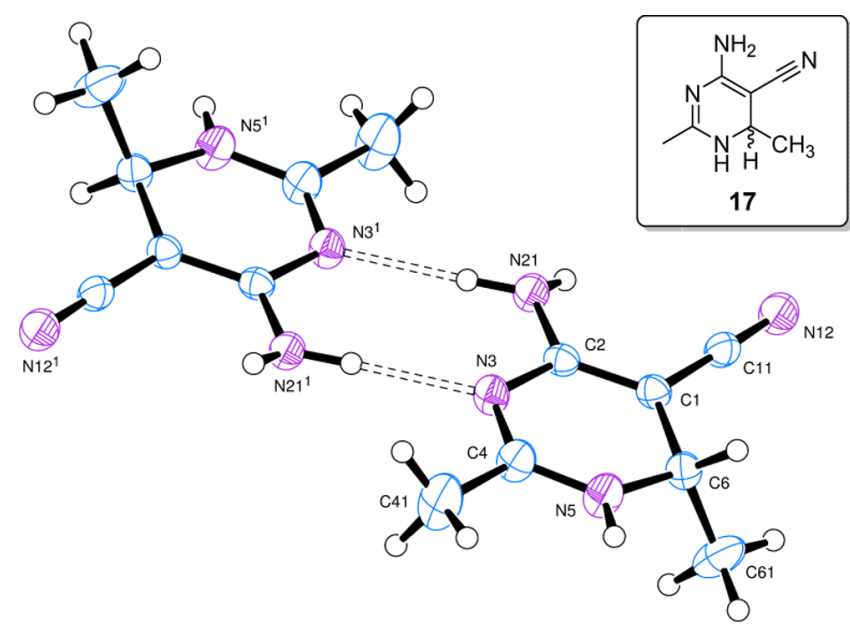

Figure 4. diagram for the crystal structure of 4-amino-2-methyl-5cyano-6-methyl-[1,2]-dihydropyrimid-ine 17 . Thermal ellipsoids are drawn at the $50 \%$ probability level.

$\mathrm{C}-\mathrm{C}$ bond $(1.5 \AA)$ and an $\mathrm{sp}^{2} \mathrm{C}=\mathrm{C}(1.3 \AA)$, thereby suggesting the presence of a partial $\mathrm{sp}^{2}$ bond character between the aromatic $\pi$-system and the nitrile bond. At C6, the CHMe position adopts the classic tetrahedral geometry with a bond angle for the atom group N5-C6-H6 at $109.0(9)^{\circ}$ and the bond length for $\mathrm{C} 1-\mathrm{C} 6$ at $1.510(2) \AA$, whereas the shorter bonds between the $\mathrm{sp}^{2}$ centers of $\mathrm{C} 1-\mathrm{C} 2$ and $\mathrm{C} 4-\mathrm{N} 3$ have lengths of $1.379(2)$ and $1.312(2) \AA$, respectively. Interestingly, these structures form a hydrogen-bonded dimer pair (racemic, with $R$ and $S$ configurations) around a center of symmetry, forming a binding pattern similar to that observed in DNA base pairs (Figure 4), which becomes extended through further pairs of hydrogen bonds (see the Supporting Information).

This paper identifies three competing pathways for the addition of Grignard reagents to the readily available 4-amino2-methyl-5-cyanopyrimidine starting material, giving access to either the sought after $\alpha$-keto-4-amino-2-methyl pyrimidines or alternative products arising from substitution of the pyrimidine ring itself. Especially in the cases where the exclusive formation of a single product has been identified, the results presented here should open the way for the exploitation of these substitution patterns in future research. Furthermore, studies are now in progress to extend the range of examples that give exclusively the unusual chiral 1,2-dihydropyrimidines to introduce alternative reactive functional groups at the C6 position (e.g., alkynes) to prepare the way for the development of an enantioselective version of the procedure.

Ideally, this research would facilitate a wider range of ongoing synthetic modifications such as Diels-Alder cycloaddition chemistry and metal-catalyzed cross-coupling reactions, which could utilize the vinyl adduct 32. Each in their own way, the intended $\alpha$-keto products and the unusual ringsubstituted products are ideal structures to access a wide range of pyrimidine-derived compounds that will be of value in medicinal and bioorganic chemistry. Our procedure avoids the need for extensive purification steps and so provides a potential "gateway compound" suited for easy functionalization in future studies. It also offers potential access to key intermediates in the substantial quantities needed for sustained biochemical/ pharmaceutical research projects and scale-up processes. ${ }^{29}$ Furthermore, the ketones made available in this way would be suitable prochiral candidates for reductions to provide useful 
intermediates for the chiral synthetic pool and/or enzymatic studies. $^{30,31}$

\section{EXPERIMENTAL SECTION}

General Considerations. All reactions were carried out in dry solvents, unless otherwise stated. Anhydrous THF, diethyl ether, and toluene were distilled over sodium following literature methods. All solvents and chemicals were purchased from appropriate suppliers including Sigma-Aldrich, Acros, TCI, Fluorochem, Alfa Aesar, and Fisher. Infrared spectra were obtained on a PerkinElmer spectrum 100 Fourier transform infrared spectrometer, with most compounds dissolved in dichloromethane and measured as a film on a $\mathrm{NaCl}$ disc. In cases where compounds were not soluble in this solvent, the infrared spectrum was obtained using an attenuation total reflection plate. ${ }^{1} \mathrm{H}$ and ${ }^{13} \mathrm{C}$ NMR spectra were obtained using a Bruker (Ascend) $500 \mathrm{MHz}$ spectrometer and a sample express autosampler. Mass spectra were measured by the EPSRC UK National Mass Spectrometry Facility, Swansea, UK using an LTQ Orbitrap XL spectrometer. Melting points were recorded on a BUCHI melting point apparatus B545. X-ray diffraction data were recorded at the UEA on an Oxford Diffraction Xcalibur-3/Sapphire3 CCD diffractometer. The data were then processed with the CrysAlisPro-CCD and -RED programs. ${ }^{32,33}$ The structure was determined by the direct method routines in the SHELXS program ${ }^{34}$ and refined by full-matrix least-squares methods on $F^{2}$ s in SHELXL ${ }^{34}$ using WinGX. ${ }^{35}$ Scattering factors for neutral atoms were taken from the International Tables for X-ray Crystallography. ${ }^{36}$

Preparation of 4-Amino-5-cyano-2-methylpyrimidine (13). ${ }^{17}$ Sodium $(0.19 \mathrm{~g})$ was added in small pieces to ethanol $(4.0 \mathrm{~mL})$ to produce a $2 \mathrm{M}$ solution of sodium ethoxide. Then, acetamide hydrochloride $(0.80 \mathrm{~g}, 8.50 \mathrm{mmol})$ was added. Filtration through celite gave a clear solution, which upon addition of ethoxymethylene malonitrile $(0.50 \mathrm{~g}, 4.10 \mathrm{mmol})$ produced a yellow precipitate that was collected by filtration and recrystallized from ethanol to give the title compound as fine yellow needles $(1.10 \mathrm{~g}, 70 \%) . \mathrm{mp} 245-247{ }^{\circ} \mathrm{C}\left[\mathrm{llit}^{17} \mathrm{mp}\right.$ 246-248 $\left.{ }^{\circ} \mathrm{C}\right] .{ }^{1} \mathrm{H}$ NMR (500 MHz, DMSO-d $\left.d_{6}\right): \delta 8.52(\mathrm{~s}$, $1 \mathrm{H}), 7.77$ (s, 2H), 2.40 (s, 3H) ppm. ${ }^{13} \mathrm{C}$ NMR (126 MHz, DMSO- $\left.d_{6}\right): \delta 170.6,162.8,161.6,116.2,87.1,26.4$ ppm. IR $\nu_{\text {max }}: 3378,3334\left(\mathrm{NH}_{2}\right), 2223(\mathrm{sp} \mathrm{CN}), 1672,1584,1542$ (C$\mathrm{H}, \mathrm{sp}^{2}$ stretch) $\mathrm{cm}^{-1}$.

Preparation of tert-Butylmagnesium Bromide. 2-Methyl2-bromopropane $(1.0 \mathrm{~mL}, 8.9 \mathrm{mmol}, 1$ equiv) in dry THF $(9.0$ $\mathrm{mL}$ ) was added dropwise to a predried round-bottom flask containing magnesium turnings $(427 \mathrm{mg}, 17.8 \mathrm{mmol}, 2.0$ equiv) in anhydrous THF $(20 \mathrm{~mL})$. After activation with a small amount of iodine, addition was maintained to keep a gentle reflux. The reaction was then stirred at room temperature ( $\mathrm{rt}$ ) for $3 \mathrm{~h}$. The Grignard reagent was titrated against 1,10-phenanthroline and isopropyl alcohol.

Typical Procedure I for the Synthesis of $\alpha$-Keto-4amino-2-methylpyrimidines (Products of Type A). 5-(4Amino-2-methylpyrimidinyl)propan-1-one (19). To 4-amino5-cyano-2-methylpyrimidine $13(200 \mathrm{mg}, 1.5 \mathrm{mmol})$ in THF $(5 \mathrm{~mL})$ was added ethylmagnesium bromide in THF (3 M, 5.3 mmol, $1.74 \mathrm{~mL}, 3.5$ equiv) dropwise at $0{ }^{\circ} \mathrm{C}$. The reaction mixture was warmed to $40{ }^{\circ} \mathrm{C}$ and left to stir overnight. The reaction was then quenched with $1 \mathrm{M} \mathrm{HCl}(10 \mathrm{~mL})$, stirred for a further $24 \mathrm{~h}$, and then extracted with EtOAc $(3 \times 10 \mathrm{~mL})$. The combined organic layers were washed with brine $(10 \mathrm{~mL})$, dried over $\mathrm{MgSO}_{4}$, filtered, and evaporated under pressure to leave a fine powder. Column chromatography on silica eluting with EtOAc/hexanes $(1: 3 \mathrm{v} / \mathrm{v})$ gave the product as a white solid (168 mg 68\%). Rf $=0.6 \mathrm{EtOAc} /$ hexanes $1: 3 \mathrm{v} / \mathrm{v} . \mathrm{mp}$ 160-162 ${ }^{\circ} \mathrm{C} .{ }^{1} \mathrm{H}$ NMR $\left(500 \mathrm{MHz}, \mathrm{CDCl}_{3}\right): \delta 8.73(\mathrm{~s}, 1 \mathrm{H})$, $8.62(\mathrm{~s}, 1 \mathrm{H}), 5.67(\mathrm{~s}, 2 \mathrm{H}), 2.87\left(\mathrm{q},{ }^{3} \mathrm{~J}=7.3 \mathrm{~Hz}, 2 \mathrm{H}, \mathrm{H}-4\right), 2.47$ (s, 3H, H-1), $1.15\left(\mathrm{t},{ }^{3} \mathrm{~J}=7.3 \mathrm{~Hz}, 3 \mathrm{H}, \mathrm{H}-5\right)$ ppm. ${ }^{13} \mathrm{C}$ NMR $\left(126 \mathrm{MHz}, \mathrm{CDCl}_{3}\right): \delta 201.4,171.1,161.9,158.9,109.2,29.5$, 26.4, $8.1 \mathrm{ppm}$. IR $\nu_{\max }: 3385,3263,3109,2980\left(\mathrm{sp}^{3} \mathrm{C}-\mathrm{H}\right.$ stretch), 1657, 1625, 1528 ( $\mathrm{sp}^{2} \mathrm{C}-\mathrm{H}$ stretch) $\mathrm{cm}^{-1}$. HRMS (ESI-LTQ Orbitrap XL) $m / z:[\mathrm{M}+\mathrm{H}]^{+}$calcd for $\mathrm{C}_{8} \mathrm{H}_{12} \mathrm{~N}_{3} \mathrm{O}$, 166.0975; found, 166.0972 .

Typical Procedure II for the Synthesis of 4-Amino-5cyano-2-alkyl- or 2-Arylpyrimidines (Products of Type B). 4-Amino-5-cyano-2-methyl-6-phenylpyrimidine (30). ${ }^{32}$ To 4-amino-5-cyano-2-methylpyrimidine 13 (200 mg, 1.5 $\mathrm{mmol})$ in THF $(5 \mathrm{~mL})$ was added phenylmagnesium bromide in THF ( $3 \mathrm{M}, 5.2 \mathrm{mmol}, 1.74 \mathrm{~mL}, 3.5$ equiv) dropwise at $0{ }^{\circ} \mathrm{C}$. The reaction was warmed to $40{ }^{\circ} \mathrm{C}$ and left to stir overnight, then quenched with $1 \mathrm{M} \mathrm{HCl}(10 \mathrm{~mL})$, and stirred for a further $24 \mathrm{~h}$. The reaction was then neutralized with aqueous $\mathrm{NaHCO}_{3}$ and extracted with EtOAc $(3 \times 10 \mathrm{~mL})$. The combined organic layers were washed with brine $(10 \mathrm{~mL})$, dried over $\mathrm{MgSO}_{4}$, filtered, and evaporated under reduced pressure to leave a fine powder. Column chromatography on silica eluting with EtOAc/hexanes (gradient, 5:1 v/v to pure EtOAc) gave the product as a white powder $(315 \mathrm{mg}, 40 \%)$. Rf $=0.2 \mathrm{EtOAc} /$ hexanes 5:1. v/v. ${ }^{1} \mathrm{H}$ NMR (500 MHz, DMSO$\left.d_{6}\right): \delta 7.87-7.82(\mathrm{~m}, 2 \mathrm{H}), 7.63-7.51(\mathrm{~m}, 3 \mathrm{H}), 2.47(\mathrm{~s}, 3 \mathrm{H})$ ppm (this compound would only dissolve in DMSO- $d_{6}$; signals for the $\mathrm{NH}_{2}$ protons were not observed because of exchange with $\mathrm{H}_{2} \mathrm{O}$ in the solvent). ${ }^{13} \mathrm{C}$ NMR $\left(126 \mathrm{MHz}\right.$, DMSO- $\left.d_{6}\right): \delta$ $169.7,168.4,164.7,136.8,131.3,129.4,129.0,116.7,84.2$, 26.4 ppm. IR $\nu_{\max }: 3379,3330\left(\mathrm{NH}_{2}\right), 2168(\mathrm{sp} \mathrm{CN}), 1680$, 1626, $1561 \mathrm{~cm}^{-1}$. HRMS (ESI-LTQ Orbitrap XL) $\mathrm{m} / z$ : $[\mathrm{M}+$ $\mathrm{H}]^{+}$calcd for $\mathrm{C}_{12} \mathrm{H}_{11} \mathrm{~N}_{4}, 211.0978$; found, 211.0978 .

Typical Procedure III for the Synthesis of 4-Amino-5cyano-2-methyl-6-alkyl- or 6-Alkenyl-[1,2]-dihydropyrimidines at $40{ }^{\circ} \mathrm{C}$ (Products of Type C). 4-Amino-5cyano-2-methyl-6-vinyl-[1,2]-dihydropyrimidine (32). To 4amino-5-cyano-2-methylpyrimidine $13(2.5 \mathrm{~g}$, $19 \mathrm{mmol}, 1$ equiv) in THF $(50 \mathrm{~mL})$ was added vinylmagnesium bromide in THF ( $3 \mathrm{M}, 65 \mathrm{mmol}, 21.8 \mathrm{~mL}, 3.5$ equiv) dropwise at 40 ${ }^{\circ} \mathrm{C}$. The reaction mixture was left to stir overnight and then quenched with saturated aqueous ammonium chloride (20 $\mathrm{mL}$ ) at $0{ }^{\circ} \mathrm{C}$ and stirred for further $48 \mathrm{~h}$ and extracted with EtOAc $(3 \times 10 \mathrm{~mL})$. The combined organic layers were washed with brine $(10 \mathrm{~mL})$, dried over $\mathrm{MgSO}_{4}$, filtered, and evaporated under reduced pressure to give the product as a fine yellow powder $(2.24 \mathrm{~g}, 76 \%) . \mathrm{mp} 171-173{ }^{\circ} \mathrm{C} .{ }^{1} \mathrm{H}$ NMR (500 $\left.\mathrm{MHz}, \mathrm{DMSO}-d_{6}\right): \delta 8.47$ (br s, $\left.1 \mathrm{H}\right), 5.88(\mathrm{~s}, 2 \mathrm{H}), 5.76$ (ddd, $\left.{ }^{3} J=16.9,9.9,6.9 \mathrm{~Hz}, 1 \mathrm{H}\right), 5.07-5.00(\mathrm{~m}, 2 \mathrm{H}), 4.49\left(\mathrm{~d},{ }^{3} \mathrm{~J}=\right.$ $6.9 \mathrm{~Hz}, 1 \mathrm{H}), 1.88(\mathrm{~s}, 3 \mathrm{H}) \mathrm{ppm} .{ }^{13} \mathrm{C}$ NMR $(126 \mathrm{MHz}, \mathrm{DMSO}-$ $\left.d_{6}\right): \delta 160.8,159.4,139.9,122.1,114.3,52.5,51.4,21.8 \mathrm{ppm}$. IR $\nu_{\max }: 3316,3302\left(\mathrm{NH}_{2}\right), 2171(\mathrm{sp} \mathrm{CN}), 1734\left(\mathrm{sp}^{2} \mathrm{CO}\right)$, $1683,1638,1601\left(\mathrm{sp}^{2} \mathrm{C}-\mathrm{H}\right.$ stretch) $\mathrm{cm}^{-1}$. HRMS (ESI-LTQ Orbitrap XL) $m / z$ : $[\mathrm{M}+\mathrm{H}]^{+}$calcd for $\mathrm{C}_{8} \mathrm{H}_{11} \mathrm{~N}_{4}, 163.0978$; found, 163.0975 .

Typical Procedure IV for the Synthesis of 4-Amino-5cyano-2-methyl-6-alkyl- or 6-Alkenyl-[1,2]-dihydropyrim-idines from $0{ }^{\circ} \mathrm{C}$ to $\mathrm{rt}$ (Products of Type C). 4-Amino5-cyano-2-methyl-6-propyl-[1,2]-dihydropyrimidine (24). To 4-amino-5-cyano-2-methylpyrimidine $13(200 \mathrm{mg}, 1.5 \mathrm{mmol})$ in anhydrous THF $(5 \mathrm{~mL})$ at $0{ }^{\circ} \mathrm{C}$ was added propylmagne- 
sium chloride ( $2 \mathrm{M}, 5.2 \mathrm{mmol}, 2.6 \mathrm{~mL}, 3.5$ equiv) dropwise at $0{ }^{\circ} \mathrm{C}$. The reaction mixture was stirred at $0{ }^{\circ} \mathrm{C}$ for $3 \mathrm{~h}$ and then left to warm to rt overnight. The reaction mixture was cooled to $0{ }^{\circ} \mathrm{C}$ and quenched with saturated aqueous ammonium chloride $(10 \mathrm{~mL})$ and left to stand for $3 \mathrm{~h}$. The product was extracted with EtOAc $(3 \times 10 \mathrm{~mL})$, washed with brine $(10$ $\mathrm{mL}$ ), dried over $\mathrm{MgSO}_{4}$, filtered, and evaporated to dryness to give the title compound as a fine yellow powder $(180 \mathrm{mg}$, 67\%). mp $163-165{ }^{\circ} \mathrm{C} .{ }^{1} \mathrm{H}$ NMR (400 MHz, DMSO- $\left.d_{6}\right): \delta$ $8.21(\mathrm{~s}, 1 \mathrm{H}), 5.74(\mathrm{~s}, 2 \mathrm{H}), 4.04(\mathrm{dd}, J=18.8,4.6 \mathrm{~Hz}, 1 \mathrm{H}), 1.84$ (s, $3 \mathrm{H}), 1.46-1.23(\mathrm{~m}, 4 \mathrm{H}), 0.92-0.88(\mathrm{~m}, 3 \mathrm{H}) \mathrm{ppm} .{ }^{13} \mathrm{C}$ NMR (101 MHz, DMSO- $\left.d_{6}\right): \delta 161.4,160.1,122.6,51.7,49.3$, $41.4,22.2,16.9,14.2 \mathrm{ppm}$. IR $\nu_{\max }: 3310,3252\left(\mathrm{NH}_{2}\right), 2100$ (CN), 1650, 1617, $1538\left(\mathrm{sp}^{2} \mathrm{C}-\mathrm{H}\right.$ stretch $) \mathrm{cm}^{-1}$. HRMS (ESI-LTQ Orbitrap XL) $m / z:[\mathrm{M}+\mathrm{H}]^{+}$calcd for $\mathrm{C}_{9} \mathrm{H}_{15} \mathrm{~N}_{4}$, 179.1291; found, 179.1291.

Synthesis of $\boldsymbol{\alpha}$-Keto-4-amino-2-methylpyrimidines. 5(4-Amino-2-methylpyrimidinyl)ethanone (18). Following procedure I, using methylmagnesium bromide followed by column chromatography on silica eluting with ethyl acetate/ hexanes $(1: 3 \mathrm{v} / \mathrm{v})$ gave the title compound as a white solid (470 mg, 50\%). mp 170-172 ${ }^{\circ} \mathrm{C} .{ }^{1} \mathrm{H}$ NMR (500 MHz, $\left.\mathrm{CDCl}_{3}\right): \delta 8.70(\mathrm{~s}, 1 \mathrm{H}), 8.57(\mathrm{~s}, 1 \mathrm{H}), 5.72(\mathrm{~s}, 1 \mathrm{H}), 2.50(\mathrm{~s}$, $3 \mathrm{H}), 2.48(\mathrm{~s}, 3 \mathrm{H}) \mathrm{ppm} .{ }^{13} \mathrm{C}$ NMR $\left(126 \mathrm{MHz}, \mathrm{CDCl}_{3}\right): \delta$ $198.2,171.4,161.8,159.8,109.8,26.6,26.1 \mathrm{ppm}$. IR $\nu_{\max }$ : $3372,3114,1651\left(\mathrm{sp}^{2} \mathrm{C}=\mathrm{O}\right), 1590,1520\left(\mathrm{sp}^{2} \mathrm{C}-\mathrm{H}\right.$ aromatic stretch) $\mathrm{cm}^{-1}$. HRMS (ESI-LTQ Orbitrap XL) $m / z:[\mathrm{M}+\mathrm{H}]^{+}$ calcd for $\mathrm{C}_{7} \mathrm{H}_{10} \mathrm{~N}_{3} \mathrm{O}$, 152.0818; found, 152.0815 .

5-(4-Amino-2-methylpyrimidinyl)butan-1-one (22). Following procedure I, using $n$-propylmagnesium bromide followed by column chromatography on silica eluting with EtOAc/hexanes $(2: 1 \mathrm{v} / \mathrm{v})$ gave the title compound as a white solid (43 mg, 16\%). Rf = 0.3 EtOAc/hexanes 2:1 v/v. mp 147-149 ${ }^{\circ} \mathrm{C} .{ }^{1} \mathrm{H}$ NMR (500 MHz, $\left.\mathrm{CDCl}_{3}\right): \delta 8.73(\mathrm{~s}, 1 \mathrm{H})$, $2.81\left(\mathrm{t},{ }^{3} \mathrm{~J}=7.4 \mathrm{~Hz}, 3 \mathrm{H}\right), 2.50(\mathrm{~s}, 3 \mathrm{H}), 1.73-1.64(\mathrm{~m}, 2 \mathrm{H}, \mathrm{H}-$ 5), $0.94\left(\mathrm{t},{ }^{3} \mathrm{~J}=7.4 \mathrm{~Hz}, 3 \mathrm{H}, \mathrm{H}-6\right) \mathrm{ppm} .{ }^{13} \mathrm{C} \mathrm{NMR}(126 \mathrm{MHz}$, $\left.\mathrm{CDCl}_{3}\right): \delta 200.6,170.5,162.0,158.2,109.3,40.3,25.8,17.9$, $13.8 \mathrm{ppm}$. IR $\nu_{\max }: 3373,3265\left(\mathrm{NH}_{2}\right) 1653,1629,1534\left(\mathrm{sp}^{2}\right.$ $\mathrm{C}-\mathrm{H}$ stretch) $\mathrm{cm}^{-1}$. HRMS (ESI-LTQ Orbitrap XL) $\mathrm{m} / z$ : [M $+\mathrm{H}]^{+}$calcd for $\mathrm{C}_{9} \mathrm{H}_{14} \mathrm{~N}_{3} \mathrm{O}$, 180.1131; found, 180.1129 .

This product was also obtained following procedure III; using n-propylmagnesium bromide followed by column chromatography on silica eluting with EtOAc/hexanes (2:1 $\mathrm{v} / \mathrm{v})$ gave the title compound as a white solid (60 mg, 22\%).

5-(4-Amino-2-methylpyrimidinyl)phenone (29). Following procedure I, using phenylmagnesium bromide followed by column chromatography on silica eluting with EtOAc/hexanes (gradient, 5:1 v/v to pure EtOAc) gave the title compound as a white powder $(200 \mathrm{mg}, 25 \%), \mathrm{Rf}=0.5 \mathrm{EtOAc} /$ hexanes $5: 1 \mathrm{v} /$ v. mp $182-184{ }^{\circ} \mathrm{C}$. ${ }^{1} \mathrm{H}$ NMR (500 MHz, DMSO- $\left.d_{6}\right): \delta 8.33$ (s, $1 \mathrm{H}), 8.12(\mathrm{~s}, 2 \mathrm{H}), 7.68-7.63(\mathrm{~m}, 3 \mathrm{H}), 7.61-7.54(\mathrm{~m}, 2 \mathrm{H})$, $2.45(\mathrm{~s}, 3 \mathrm{H}) \mathrm{ppm} .{ }^{13} \mathrm{C}$ NMR $\left(126 \mathrm{MHz}, \mathrm{DMSO}-d_{6}\right): \delta 196.2$, $170.63,162.8,161.8,138.6,132.5,129.4,129.0,108.9,26.3$ ppm. IR $\nu_{\text {max }}: 3381,2925,1627,1577,1598\left(\mathrm{sp}^{2} \mathrm{C}-\mathrm{H}\right.$ stretch $)$ $\mathrm{cm}^{-1}$. HRMS (ESI-LTQ Orbitrap XL) $\mathrm{m} / z:[\mathrm{M}+\mathrm{H}]^{+} \mathrm{calcd}$ for $\mathrm{C}_{12} \mathrm{H}_{12} \mathrm{~N}_{3} \mathrm{O}$, 214.0975; found, 214.0973.

Synthesis of 4-Amino-5-cyano-2-alkyl- or 2-Arylpyrimidines. 4-Amino-5-cyano-6-ethyl-2-methylpyrimidine (20). ${ }^{27}$ Following procedure II, using methylmagnesium bromide followed by column chromatography on silica eluting with EtOAc/hexanes (gradient, 1:1 v/v to pure EtOAc) gave the title compound as a white powder $(66 \mathrm{mg}, 27 \%) . \mathrm{Rf}=0.7$ EtOAc/hexanes 1:1 v/v. mp 197-199 ${ }^{\circ} \mathrm{C}\left[\right.$ lit. $^{27} \mathrm{mp} \mathrm{193-194}$ $\left.{ }^{\circ} \mathrm{C}\right] .{ }^{1} \mathrm{H}$ NMR $\left(500 \mathrm{MHz}, \mathrm{CDCl}_{3}\right): \delta 5.42(\mathrm{~s}, 2 \mathrm{H}), 2.66\left(\mathrm{q},{ }^{3} J\right.$ $=7.6 \mathrm{~Hz}, 2 \mathrm{H}), 2.38(\mathrm{~s}, 3 \mathrm{H}), 1.16\left(\mathrm{t},{ }^{3} \mathrm{~J}=7.6 \mathrm{~Hz}, 3 \mathrm{H}\right) \mathrm{ppm} .{ }^{13} \mathrm{C}$ NMR $\left(126 \mathrm{MHz}, \mathrm{CDCl}_{3}\right): \delta 175.5,170.4,163.3,115.3,86.3$, $30.6,26.4,12.8$ ppm. IR $\nu_{\max }: 3377,3340\left(\mathrm{NH}_{2}\right), 2223(\mathrm{CN})$, 1682, 1553, $1577\left(\mathrm{sp}^{2} \mathrm{C}-\mathrm{H}\right.$ stretch) $\mathrm{cm}^{-1}$. HRMS (ESI-LTQ Orbitrap XL) $m / z:[\mathrm{M}+\mathrm{H}]^{+}$calcd for $\mathrm{C}_{8} \mathrm{H}_{11} \mathrm{~N}_{4}, 163.0978$; found, 163.0974 .

4-Amino-5-cyano-2-methyl-6-propylpyrimidine (23). Following procedure II, using $n$-propylmagnesium bromide followed by column chromatography on silica eluting with EtOAc/hexanes $(2: 1 \mathrm{v} / \mathrm{v})$ gave the title compound as a yellow/white powder $(53 \mathrm{mg}, 20 \%) . \mathrm{Rf}=0.6 \mathrm{EtOAc} /$ hexanes 2:1 v/v. mp $176-177{ }^{\circ} \mathrm{C} .{ }^{1} \mathrm{H}$ NMR $\left(500 \mathrm{MHz}, \mathrm{CDCl}_{3}\right): \delta$ $5.50(\mathrm{~s}, 2 \mathrm{H}), 2.71\left(\mathrm{t},{ }^{3} \mathrm{~J}=10 \mathrm{~Hz}, 2 \mathrm{H}\right), 2.47(\mathrm{~s}, 3 \mathrm{H}), 1.75-1.66$ $(\mathrm{m}, 2 \mathrm{H}), 0.94\left(\mathrm{t},{ }^{3} \mathrm{~J}=7.4 \mathrm{~Hz}, 3 \mathrm{H}\right) \mathrm{ppm} .{ }^{13} \mathrm{C} \mathrm{NMR}(126 \mathrm{MHz}$, $\left.\mathrm{CDCl}_{3}\right): \delta 173.0,169.1,162.1,114.1,85.6,37.5,25.1,21.2$, 12.4 ppm. IR $\nu_{\max }: 3368,3338\left(\mathrm{NH}_{2}\right) 1653,1629,224(\mathrm{CN})$, 1678, 1553, 1417 ( $\mathrm{sp}^{2} \mathrm{C}-\mathrm{H}$ stretch) $\mathrm{cm}^{-1}$. HRMS (ESI-LTQ Orbitrap XL) $m / z:[\mathrm{M}+\mathrm{H}]^{+}$calcd for $\mathrm{C}_{9} \mathrm{H}_{13} \mathrm{~N}_{4}, 177.1135$; found, 177.1133 .

4-Amino-6-butyl-5-cyano-2-methylpyrimidine (25). Following procedure II, using $n$-butylmagnesium bromide followed by column chromatography on silica eluting with EtOAc/hexanes (gradient, 1:1 v/v to pure EtOAc) gave the title compound as a white solid $(50 \mathrm{mg}, 18 \%) . \mathrm{Rf}=0.6$ EtOAc/hexanes 1:1 v/v. mp 180-182 ${ }^{\circ} \mathrm{C} .{ }^{1} \mathrm{H}$ NMR (500 $\mathrm{MHz}_{\mathrm{CDCl}}$ ): $\delta 5.69(\mathrm{~s}, 2 \mathrm{H}), 2.72\left(\mathrm{t},{ }^{3} \mathrm{~J}=10 \mathrm{~Hz}, 2 \mathrm{H}\right), 2.46$ $(\mathrm{s}, 3 \mathrm{H}), 1.68-1.60(\mathrm{~m}, 2 \mathrm{H}), 1.40-1.31(\mathrm{~m}, 2 \mathrm{H}), 0.88\left(\mathrm{t},{ }^{3} \mathrm{~J}=\right.$ $7.4 \mathrm{~Hz}, 3 \mathrm{H}) \mathrm{ppm} .{ }^{13} \mathrm{C} \mathrm{NMR}\left(126 \mathrm{MHz}, \mathrm{CDCl}_{3}\right): \delta$ 175.2, 170.4, 163.6, 116.0, 87.1, 37.0, 31.6, 26.8, 23.1, 14.2 ppm. IR $\nu_{\max }: 3339,3379,2227$ (sp CN), 1687, 1559, $1461\left(\mathrm{sp}^{2} \mathrm{C}-\mathrm{H}\right.$ stretch) $\mathrm{cm}^{-1}$. HRMS (ESI-LTQ Orbitrap XL) $m / z:[\mathrm{M}+\mathrm{H}]^{+}$ calcd for $\mathrm{C}_{10} \mathrm{H}_{15} \mathrm{~N}_{4}, 191.1291$; found, 191.1289.

Synthesis of 4-Amino-5-cyano-2-methyl-6-alkyl- or -6-Phenyl- or 6-Alkenyl-[1,2]-dihydropyrimdines. 4Amino-5-cyano-2,6-dimethyl-[1,2]-dihydropyrimidine (17). Following procedure III, using methylmagnesium bromide gave the title compound as a fine yellow powder $(2.4 \mathrm{~g}, 85 \%)$. mp 221-222 ${ }^{\circ} \mathrm{C}$. ${ }^{1} \mathrm{H}$ NMR (500 MHz, DMSO- $d_{6}$ ): $\delta 8.27$ (s, $1 \mathrm{H}), 5.77(\mathrm{~s}, 2 \mathrm{H}), 4.17\left(\mathrm{q},{ }^{3} J=6.0 \mathrm{~Hz}, 1 \mathrm{H}\right), 1.84(\mathrm{~s}, 3 \mathrm{H}), 1.18$ $\left(\mathrm{d},{ }^{3} \mathrm{~J}=6.0 \mathrm{~Hz}, 3 \mathrm{H}\right) \mathrm{ppm} .{ }^{13} \mathrm{C}$ NMR $\left(126 \mathrm{MHz}, \mathrm{DMSO}-d_{6}\right): \delta$ 161.0, 159.7, 122.4, 53.6, 45.5, 25.5, $22.1 \mathrm{ppm}$. IR $\nu_{\max }: 3399$, $3304,2152$ ( $\mathrm{sp} \mathrm{CN}), 1658,1608,1563$ ( $\mathrm{sp}^{2} \mathrm{C}-\mathrm{H}$ stretch) $\mathrm{cm}^{-1}$. HRMS (ESI-LTQ Orbitrap XL) $\mathrm{m} / z:[\mathrm{M}+\mathrm{H}]^{+} \mathrm{calcd}$ for $\mathrm{C}_{7} \mathrm{H}_{11} \mathrm{~N}_{4}, 151.0978$; found, 151.0975 .

4-Amino-5-cyano-6-ethyl-2-methyl-[1,2]-dihydropyrimidine (21). Following procedure III, using ethylmagnesium bromide gave the title compound as a fine yellow powder $(2.1$ g, 80\%). mp 213-215 ${ }^{\circ} \mathrm{C} .{ }^{1} \mathrm{H}$ NMR (500 MHz, DMSO- $\left.d_{6}\right): \delta$ 8.19 (s, $1 \mathrm{H}, \mathrm{H}-6), 5.75$ (s, 2H, H-2), 4.09 (td, ${ }^{3} \mathrm{~J}=4.6,2.3 \mathrm{~Hz}$, $1 \mathrm{H}), 1.86(\mathrm{~s}, 3 \mathrm{H}), 1.50-1.38(\mathrm{~m}, 2 \mathrm{H}), 0.86\left(\mathrm{t},{ }^{3} \mathrm{~J}=7.4 \mathrm{~Hz}\right.$, $3 \mathrm{H}) \mathrm{ppm} .{ }^{13} \mathrm{C}$ NMR $\left(126 \mathrm{MHz}, \mathrm{DMSO}-d_{6}\right): \delta 161.5,160.3$, $122.7,51.0,50.6,31.2,21.7,8.1$ ppm. IR $\nu_{\max }: 3372,3326$ $\left(\mathrm{NH}_{2}\right), 2180,2149$ (sp CN), 1659, 1600, $1565\left(\mathrm{sp}^{2} \mathrm{C}-\mathrm{H}\right.$ stretch) $\mathrm{cm}^{-1}$. HRMS (ESI-LTQ Orbitrap XL) $m / z:[\mathrm{M}+\mathrm{H}]^{+}$ calcd for $\mathrm{C}_{8} \mathrm{H}_{13} \mathrm{~N}_{4}$, 165.1135; found, 165.1135.

4-Amino-6-butyl-5-cyano-2-methyl-[1,2]-dihydropyrimidine (26). Following procedure IV, using $n$-butylmagnesium bromide gave the title compound as a fine yellow powder $(250$ $\mathrm{mg}, 87 \%) .{ }^{1} \mathrm{H}$ NMR (500 MHz, DMSO- $\left.d_{6}\right): \delta 8.22(\mathrm{~s}, 1 \mathrm{H})$, $5.74(\mathrm{~s}, 2 \mathrm{H}), 4.08(\mathrm{td}, J=4.8,2.4 \mathrm{~Hz}, 1 \mathrm{H}), 1.86(\mathrm{~s}, 3 \mathrm{H})$, $1.45-1.40(\mathrm{~m}, 2 \mathrm{H}), 1.34-1.25(\mathrm{~m}, 4 \mathrm{H}), 0.90(\mathrm{t}, J=6.9 \mathrm{~Hz}$, $3 \mathrm{H})$ ppm. ${ }^{13} \mathrm{C}$ NMR (126 MHz, DMSO): $\delta 161.1,160.2$, 
122.3, 51.3, 49.6, 38.4, 25.4, 22.8, 21.9, 14.5 ppm. IR $\nu_{\max }$ : 2159 (sp CN), 1631, 1588, $1520 \mathrm{~cm}^{-1}$. HRMS (ESI-LTQ Orbitrap XL) $m / z$ : $[\mathrm{M}+\mathrm{H}]^{+}$calcd for $\mathrm{C}_{10} \mathrm{H}_{17} \mathrm{~N}_{4}, 193.1448$; found, 193.1447 .

4-Amino-5-cyano-2-methyl-6-iso-propyl-[1,2]-dihydropyrimidine (27). Following procedure IV, using iso-propylmagnesium bromide gave the title compound as a fine yellow powder (150 mg, 56\%) mp 170-171 ${ }^{\circ} \mathrm{C}$. ${ }^{1} \mathrm{H}$ NMR (400 MHz, DMSO- $\left.d_{6}\right): \delta 8.14(\mathrm{~s}, 1 \mathrm{H}), 5.75(\mathrm{~s}, 2 \mathrm{H}), 3.89(\mathrm{~d}, J=2.6 \mathrm{~Hz}$, $1 \mathrm{H}), 1.87(\mathrm{~s}, 3 \mathrm{H}), 1.57(\mathrm{~s}, 1 \mathrm{H}), 0.86(\mathrm{~d}, 3 \mathrm{H}), 0.82(\mathrm{~d}, 3 \mathrm{H})$ ppm. ${ }^{13} \mathrm{C}$ NMR (101 MHz, DMSO- $\left.d_{6}\right): \delta 162.1,160.8,123.0$, 55.4, 49.9, 36.7, 21.7, 17.3, 16.4 ppm. IR $\nu_{\max }: 3368,3321$ $\left(\mathrm{NH}_{2}\right), 2175(\mathrm{CN}), 1652,1601,1565\left(\mathrm{sp}^{2} \mathrm{C}-\mathrm{H}\right.$ stretch $)$ $\mathrm{cm}^{-1}$. HRMS (ESI-LTQ Orbitrap XL) $m / z:[\mathrm{M}+\mathrm{H}]^{+}$calcd for $\mathrm{C}_{9} \mathrm{H}_{15} \mathrm{~N}_{4}, 179.1291$; found, 179.1290 .

4-Amino-5-cyano-2-methyl-6-tert-butyl-[1,2]-dihydropyrimidine (28). Following procedure III, using tert-butylmagnesium bromide gave the title compound as a fine yellow powder (120 mg, 42\%). mp 217-219 ${ }^{\circ} \mathrm{C} .{ }^{1} \mathrm{H}$ NMR (500 MHz, DMSO- $\left.d_{6}\right): \delta 8.38(\mathrm{~s}, 1 \mathrm{H}), 5.82(\mathrm{~s}, 2 \mathrm{H}), 3.61(\mathrm{~s}, 1 \mathrm{H}), 1.96(\mathrm{~s}$, $3 \mathrm{H}), 0.85$ (s, 9H) ppm. ${ }^{13} \mathrm{C}$ NMR $\left(126 \mathrm{MHz}, \mathrm{DMSO}-d_{6}\right): \delta$ 161.9, 161.6, 124.2, 58.9, 48.9, 40.8, 25.0, 21.9 ppm. IR $\nu_{\max }$ : 2159 (sp CN), 1637, 1598, $1562 \mathrm{~cm}^{-1}$. HRMS (ESI-LTQ Orbitrap XL) $m / z$ : $[\mathrm{M}+\mathrm{H}]^{+}$calcd for $\mathrm{C}_{10} \mathrm{H}_{17} \mathrm{~N}_{4}, 193.1448$; found, 193.1445 .

4-Amino-5-cyano-2-methyl-6-phenyl-[1,2]-dihydropyrimidine (31). Following procedure IV, using phenylmagnesium bromide gave the title compound as a fine yellow powder $(256$ $\mathrm{mg}, 81 \%) .{ }^{1} \mathrm{H}$ NMR (400 MHz, DMSO- $\left.d_{6}\right): \delta 8.79(\mathrm{br} \mathrm{s}, 1 \mathrm{H})$, 7.4-7.37 (m, 2H), 7.31-7.27 (m, 3H), $5.91(\mathrm{~s}, 2 \mathrm{H}), 5.11(\mathrm{~s}$ $1 \mathrm{H}), 1.92(\mathrm{~s}, 3 \mathrm{H}) \mathrm{ppm} .{ }^{13} \mathrm{C}$ NMR $\left(101 \mathrm{MHz}, \mathrm{DMSO}-d_{6}\right): \delta$ $145.9,129.4,129.0,128.2,127.9,127.2,127.0,122.4,53.8$, 22.1. IR $\nu_{\max }: 3345,3317\left(\mathrm{NH}_{2}\right), 2123(\mathrm{CN}), 1646,1601$, $1550\left(\mathrm{sp}^{2} \mathrm{C}-\mathrm{H}\right.$ stretch) $\mathrm{cm}^{-1}$ HRMS (ESI-LTQ Orbitrap XL) $m / z:[\mathrm{M}+\mathrm{H}]^{+}$calcd for $\mathrm{C}_{12} \mathrm{H}_{13} \mathrm{~N}_{4}, 213.1135$; found, 213.1137 .

\section{ASSOCIATED CONTENT}

\section{S Supporting Information}

The Supporting Information is available free of charge on the ACS Publications website at DOI: 10.1021/acsomega.8b01137.

Copies of ${ }^{1} \mathrm{H}$ and ${ }^{13} \mathrm{C}$ NMR spectra for all new compounds and X-ray structure details for compound 17 (PDF)

Crystallographic data for compound 17 (CIF)

\section{AUTHOR INFORMATION}

\section{Corresponding Author}

*E-mail: g.r.stephenson@uea.ac.uk.

\section{ORCID}

G. Richard Stephenson: 0000-0003-1487-9178

\section{Author Contributions}

The manuscript was written through contributions of all authors. All authors have given approval to the final version of the manuscript, and all authors have contributed equally.

Notes

The authors declare no competing financial interest.

\section{ACKNOWLEDGMENTS}

We thank the EU Interreg Trans Manche/Channel crossborder project "Academy-Industry Chemistry Channel" (AIcc: ref 4196) for the financial support and the EPSRC mass spectrometry facility at the University of Swansea for HRMS data.

\section{REFERENCES}

(1) (a) Wang, C.; Cai, J.; Zhang, M.; Zhao, X. Ag-Assisted Fluorination of Unprotected 4,6-Disubstituted 2-Aminopyrimidines with Selectfluor. J. Org. Chem. 2017, 82, 1260-1265. (b) Schmidt, E. Y.; Tatarinova, I. V.; Protsuk, N. I.; Ushakov, I. A.; Trofimov, B. A. A One-Pot Synthesis of 2-Aminopyrimidines from Ketones, Arylacetylenes, and Guanidine. J. Org. Chem. 2017, 82, 119-125. (c) Chi, Y.; Yan, H.; Zhang, W.-X.; Xi, Z. Back Cover: CuOTf-Catalyzed Selective Generation of 2-Aminopyrimidines from Carbodiimides and Diaryliodonium Salts by a Triple $\mathrm{C}\left(\mathrm{sp}^{3}\right)-\mathrm{H}$ Functionalization. Chem.Eur. J. 2017, 23, 977. (d) Phan, N. H. T.; Kim, H.; Shin, H.; Lee, H.S.; Sohn, J.-H. Org. Lett. 2016, 18, 5154. (e) Wei, K.-J.; Quan, Z.-j.; Zhang, Z.; Da, Y.-X.; Wang, X.-c. Copper(I) chloride promoted Csp²$\mathrm{N}$ cross-coupling of 1,2-di(pyrimidin-2-yl) disulfides with amines: an efficient approach to obtain $\mathrm{C} 2$-amino functionalized pyrimidines. Org. Biomol. Chem. 2016, 14, 2395-2398. (f) Jawale, D. V.; Pratap, U. R.; Bhosale, M. R.; Mane, R. A. One-Pot Three-Component Synthesis of 2-Amino Pyrimidines in Aqueous PEG-400 at Ambient Temperature. J. Heterocycl. Chem. 2016, 53, 1626-1630. (g) Liu, C.; Cui, Z.; Yan, X.; Qi, Z.; Ji, M.; Li, X. Synthesis, Fungicidal Activity and Mode of Action of 4-Phenyl-6-trifluoromethyl-2-aminopyrimidines against Botrytis cinerea. Molecules 2016, 21, 828.

(2) Chen, P.; Song, C.-x.; Wang, W.-s.; Yu, X.-1.; Tang, Y. TfOHmediated $[2+2+2]$ cycloadditions of ynamides with two discrete nitriles: synthesis of 4-aminopyrimidine derivatives. RSC Adv. 2016, 6, 80055-80058.

(3) Elkanzi, N. A. A.; Aly, A. A.; Shawky, A. M.; El-Sheref, E. M.; Morsy, N. M.; El-Reedy, A. A. M. Amination of Malononitrile Dimer to Amidines: Synthesis of 6-aminopyrimidines. J. Heterocycl. Chem. 2016, 53, 1941-1944.

(4) De Clercq, E. HIV resistance to reverse transcriptase inhibitors. Biochem. Pharmacol. 1994, 47, 155-169.

(5) Aggarwal, S. K.; Gogu, S. R.; Rangan, S. R. S.; Agrawal, K. C. Synthesis and biological evaluation of prodrugs of zidovudine. J. Med. Chem. 1990, 33, 1505-1510.

(6) Iqbal, A.; Sahraoui, E.-H.; Leeper, F. J. Gold(I)-catalysed synthesis of a furan analogue of thiamine pyrophosphate. Beilstein $J$. Org. Chem. 2014, 10, 2580-2585.

(7) Erixon, K. M.; Dabalos, C. L.; Leeper, F. J. Synthesis and biological evaluation of pyrophosphate mimics of thiamine pyrophosphate based on a triazole scaffold. Org. Biomol. Chem. 2008, 6, 3561.

(8) Stogryn, E. L. Synthesis of trimethoprim variations. Replacement of methylene by polar groupings. J. Med. Chem. 1972, 15, 200-201.

(9) Reddick, J. J.; Saha, S.; Lee, J.-m.; Melnick, J. S.; Perkins, J.; Begley, T. P. The mechanism of action of bacimethrin, a naturally occurring thiamin antimetabolite. Bioorg. Med. Chem. Lett. 2001, 11, $2245-2248$.

(10) Bettendorff, L.; Weekers, L.; Wins, P.; Schoffeniels, E. Injection of sulbutiamine induces an increase in thiamine triphosphate in rat tissues. Biochem. Pharmacol. 1990, 40, 2557-2560.

(11) Balakumar, P.; Rohilla, A.; Krishan, P.; Solairaj, P.; Thangathirupathi, A. The multifaceted therapeutic potential of benfotiamine. Pharmacol. Res. 2010, 61, 482-488.

(12) Hirsch, J. A.; Parrott, J. New Considerations on the Neuromodulatory Role of Thiamine. Pharmacology 2012, 89, 111116.

(13) Nagarajaiah, H.; Mukhopadhyay, A.; Moorthy, J. N. Biginelli reaction: an overview. Tetrahedron Lett. 2016, 57, 5135-5149.

(14) Ryabukhin, S. V.; Plaskon, A. S.; Ostapchuk, E. N.; Volochnyuk, D. M.; Tolmachev, A. A. Synthesis 2007, 417. 
(15) Ahmad, O. K.; Hill, M. D.; Movassaghi, M. Synthesis of Densely Substituted Pyrimidine Derivatives. J. Org. Chem. 2009, 74, 8460-8463.

(16) Williams, R. R.; Cline, J. K. Synthesis of Vitamin B1. J. Am. Chem. Soc. 1936, 58, 1504-1505.

(17) Bennett, L. R.; Blankley, C. J.; Fleming, R. W.; Smith, R. D.; Tessman, D. K. Antihypertensive activity of 6-arylpyrido[2,3d]pyrimidin-7-amine derivatives. J. Med. Chem. 1981, 24, 382-389.

(18) Zoltewicz, J. A.; Uray, G.; Baugh, T. D.; Schultz, H. Mechanism of nucleophilic substitution of thiamine and its analogs: Methanol and water solvents. Bioorg. Chem. 1985, 13, 135-149.

(19) Kwiecień, A.; Ciunik, Z. Stable Hemiaminals: 2Aminopyrimidine Derivatives Molecules 2015, 20, 14365-14376.

(20) (a) Belov, V. N.; Savchenko, A. I.; Sokolov, V. V.; Straub, A.; de Meijere, A. A New and Productive Route to 1-Heteroarylcyclopropanols. Eur. J. Org. Chem. 2003, 551-561. (b) Berdini, V.; Carr, M. G.; Congreve, M. S.; Frederickson, M.; Griffiths-Jones, C. M.; Hamlett, C. C. F.; Madin, A.; Murray, C. W.; Benning, R. K.; Saxty, G.; Vickerstaffe, E.; Woodhead, A. J.; Woodhead, S. J.; Freyne, E. J. E.; Govaerts, T. C. H.; Angibaud, P. R.; Williams, B. J. PCT Int. Appl. WO2009150240 A1, 2009, 20091217.

(21) Gim, H. J.; Li, H.; Jung, S. R.; Park, Y. J.; Ryu, J.-H.; Chung, K. $\mathrm{H}$.; Jeon, R. Design and synthesis of azaisoflavone analogs as phytoestrogen mimetics. Eur. J. Med. Chem. 2014, 85, 107-118.

(22) Abd-Elfattah, A. M.; Hussain, S. M.; El-Reedy, A. M.; Yousif, N. M. Reactions with $\alpha$-substituted cinnamonitriles. Tetrahedron 1983, 39, 3197-3199.

(23) Klimova, E. I.; Flores-Alamo, M.; Stivalet, J. M. M.; Klimova, T. Heterocycles 2012, 85, 2505.

(24) Lyle, R. E.; White, E. Reaction of organometallic reagents with pyridinium ions. J. Org. Chem. 1971, 36, 772-777.

(25) Schlenk, W.; Schlenk, W. Über die Konstitution der Grignardschen Magnesiumverbindungen. Chem. Ber. 1929, 62, 920-924.

(26) Butters, M.; Ebbs, J.; Green, S. P.; MacRae, J.; Morland, M. C.; Murtiashaw, C. W.; Pettman, A. J. Process Development of Voriconazole: A Novel Broad-Spectrum Triazole Antifungal Agent. Org. Process Res. Dev. 2001, 5, 28-36.

(27) Sundoro, B.; Chang, C.-Y.; Aslanian, R.; Jordan, F. The Synthesis of C-6'-Methylthiamin and C-6'-Ethylthiamin. Synthesis 1983, 555-556.

(28) Kenner, G. W.; Lythgoe, B.; Todd, A. R.; Topham, A. 102. Some reactions of amidines with derivatives of malonic acid. J. Chem. Soc. 1943, 388.

(29) Blaser, H. U. The chiral pool as a source of enantioselective catalysts and auxiliaries. Chem. Rev. 1992, 92, 935-952.

(30) Létinois, U.; Schütz, J.; Härter, R.; Stoll, R.; Huffschmidt, F.; Bonrath, W.; Karge, R. Lewis Acid-Catalyzed Synthesis of 4Aminopyrimidines: A Scalable Industrial Process. Org. Process Res. Dev. 2013, 17, 427-431.

(31) Nakata, T.; Fukui, M.; Ohtsuka, H.; Oishi, T. Stereoselective acyclic ketone reduction. Tetrahedron 1984, 40, 2225-2231.

(32) Dornow, A.; Hinz, E. Synthesen stickstoffhaltiger Heterocyclen, XVIII. Überortho-Kondensationen heterocyclischero-Amino-carbonsäure-Derivate. Chem. Ber. 1958, 91, 1834-1840.

(33) Programs CrysAlisPro; Oxford Diffraction Ltd.: Abingdon, UK, 2010

(34) Sheldrick, G. M. SHELX-97-Programs for crystal structure determination (SHELXS) and refinement (SHELXL). Acta Crystallogr., Sect. A: 2008, 64, 112 DOI: 10.1107/S0108767307043930.

(35) Farrugia, L. J. WinGXandORTEP for Windows: an update. J. Appl. Crystallogr. 2012, 45, 849-854.

(36) International Tables for X-ray Crystallography; Kluwer Academic Publishers: Dordrecht, 1992; Vol. C, pp 500, 219 and 193. 